\title{
STRUCTURAL FILM-LAYING MACHINES FOR USE IN COMB PLANTING OF POTATOES
}

Irina Gasparyan, Aleksandr Levshin, Sergey Shchigolev, Shagen Gasparyan

Russian Timiryazev State Agrarian University, Russia

irina150170@yandex.ru, alev200151@rambler.ru, sergeysch127@mail.ru, schagen2010@yandex.ru

\begin{abstract}
Currently, there are changes in climatic conditions: abrupt changes in temperature, humidity, strong winds, etc. Returning frosts are still possible in our zone until the end of the first decade of June. Climate variability affects the productivity of agricultural crops. For sustainable development of crops and the creation of favorable conditions for the growth and development of plants, and obtaining an early harvest, we can use the technology of covering early potato plantings using film stackers. There are various designs of film stackers, but there are features of covering the film along the ridge for growing early potatoes. Taking into account the peculiarities of growing potatoes on the ridge and covering the plantings to obtain early production was the goal of our work. A film stacker is proposed, which is adapted to the ridge technology of potato planting. The device works in the following way. When the film stacker passes over the field, a reel with the film or covering material is unwound. The covering material is pressed with a roller and then, due to the leveling fingers, is laid over the row, followed by the closing working bodies, which pour a loose layer of soil on each side on the edges of the film. A dense roller is formed, which securely fixes and presses the edges of the film to the soil. The design features of the film stacker reduce damage to the film and improve the quality of covering the ridges of early potato plantings, which provides an optimal water-temperature regime for plants in the first period of plant growth.
\end{abstract}

Keywords: potatoes, film stacker, covering material, frost.

\section{Introduction}

Currently, more and more changes in climatic conditions are observed. Leading climatologists from 52 countries have published the UN Special Report on Climate Change, they provide a comprehensive overview and view the Earth as a "critical resource". We personally observe the extreme nature of the climate: sharp temperature changes, strong winds, drought in some places, and torrential rains and floods in others, etc. Climate variability affects the productivity of agricultural crops [1-3]. To reduce negative phenomena and regulate the thermal regime, especially in the initial period of development, covering materials can be used.

Covering materials are used for growing strawberries, lettuce, cucumbers, watermelons, cabbage seedlings, early potatoes, etc. [4-5]. The presence of transparent films, non-transparent fabric materials of white or black color makes it possible to expand their application. As you know, the covering of the covering material allows, through shading, to limit the growth of weeds, due to the thermal properties, to reduce the percentage of plant death due to returning frosts in the first period of growth (especially for vegetables and potatoes, which cannot tolerate a drop in temperature below $0{ }^{\circ} \mathrm{C}$ ), or cold fogs, reduce the evaporation of moisture from the soil, as well as nutrients from the soil [6-7; 8]. Covering material protects plants from pests, hail [9]. Under the film or covering material, favorable conditions are created for the growth and development of plants; in the spring, the soil covered with a film or covering material warms up about two weeks earlier, which makes it possible to increase the productivity and obtain earlier products of excellent quality [3].

To reduce climatic risks and ensure stable production of agricultural products, you can use a variety of covering materials: vegetable or synthetic. In a number of foreign countries (Japan, USA, Italy, France, Israel, etc.), covering is carried out on hundreds of hectares, and in our country in recent years, polymer films and non-woven materials are increasingly used in large on farms [10]. This technology is increasingly being used and relevant for early production.

Abroad, strawberry plantations are also mulched: in Germany, Sweden-the best is considered to be a PVC film, in Italy-the soil is covered with a plastic film, the thickness of which is determined by the period of use: $0.05 \mathrm{~mm}-1$ year; $0.10 \mathrm{~mm}-2$ years; $0.15 \mathrm{~mm}-3$ years. Accelerated ripening of berries was noted. Several single-operation machines are used in Sweden and Italy to form mulched ridges, spread the film, and perforate it [11].

The company "Netafim" (Israel) offers a system of growing strawberries in tunnel shelters using mulching and drip irrigation to obtain an early harvest of strawberries. For mulching the soil, a dark film with a thickness of $0.04 \ldots 0.05 \mathrm{~mm}$ is used. The effects of this method of cultivation are highlighted: 
weed suppression, an increase in temperature in the root system (by about $2{ }^{\circ} \mathrm{C}$ ), economical use of irrigation water, uniform soil moisture in the root area, harvesting is possible at any time, regardless of watering, automation of the irrigation process and combined fertilizing, no flushing of pesticides applied to the leaves during watering [11].

Covering crops is a laborious process and film stackers are used for mechanization [12-14]. There are various designs of film stackers, but there are features of covering the film along the ridge for the cultivation of early potatoes [8; 15]. Taking into account the peculiarities of potato cultivation on the ridge and mechanized covering of plantings to obtain early production was the goal of our work.

\section{Materials and methods}

Analysis of climatic conditions and climatic risks in the Moscow region (frosts - Table 1), comparative analysis and existing film stackers for use on potato plantings.

Table 1

Spring frosts, 1990 ... 2019

\begin{tabular}{|c|c|c|c|c|c|}
\hline $\begin{array}{c}\text { Day, month } \\
\text { and year }\end{array}$ & Freezing, ${ }^{\mathbf{}} \mathbf{C}$ & $\begin{array}{c}\text { Day, month } \\
\text { and year }\end{array}$ & Freezing, ${ }^{\mathbf{o}} \mathbf{C}$ & $\begin{array}{c}\text { Day, month } \\
\text { and year }\end{array}$ & Freezing, ${ }^{\mathbf{}} \mathbf{C}$ \\
\hline 10.04 .1990 & -3.1 & 13.05 .2000 & -0.2 & 27.04 .2010 & -0.4 \\
\hline 11.05 .1991 & -1.1 & 04.04 .2001 & -1.2 & 21.04 .2011 & -1.5 \\
\hline 26.04 .1992 & -2.2 & 12.04 .2002 & -0.5 & 14.04 .2012 & -1.0 \\
\hline 22.04 .1993 & -2.1 & 28.04 .2003 & -2.4 & 23.04 .2013 & -0.8 \\
\hline 15.05 .1994 & -1.7 & 15.05 .2004 & -1.1 & 11.04 .2014 & -5.3 \\
\hline 12.05 .1995 & -1.3 & 22.04 .2005 & -3.2 & 26.04 .2015 & -0.2 \\
\hline 19.04 .1996 & -2.0 & 01.05 .2006 & -0.6 & 17.04 .2016 & -1.0 \\
\hline 25.04 .1997 & -0.2 & 06.05 .2007 & -1.1 & 11.05 .2017 & -0.4 \\
\hline 22.04 .1998 & -0.3 & 08.05 .2008 & -2.8 & 31.03 .2018 & -4.1 \\
\hline 10.05 .1999 & -2.1 & 25.04 .2009 & -0.3 & 07.04 .2019 & -2.1 \\
\hline
\end{tabular}

\section{Research results}

To minimize the effects of climate change, reduce the dependence of products on weather disasters and adapt to these changes, it is necessary to justify technological methods and requirements for devices to manage such risks.

In the conditions of the Moscow region, it is necessary to protect early plantings of crops from returning cold weather, which can damage plant shoots [14]. Frost data are presented in Table 1.

Twenty-year data show a decrease in temperatures below $1.0^{\circ} \mathrm{C}$. In 2020 , frosts were observed on the night of May 21 and reached $-1.5^{\circ} \mathrm{C}$ in some areas of the Moscow region, by this time there were early potato shoots. Seedlings of potato plants are very sensitive to low temperatures: they turn black and die [14]. From Table 1, the probability of frost is before $1.04-1$ day (probability $3.3 \%$; from 1 to 10.04 - 3 days (probability $10 \%$; from 11 to 20.04 - 5 days (16.7\%); from 21 to $30.04-11$ days (36.7\%); from 1 to $10.05-5$ days (probability 16.7\%) and from 11.05 and later -5 days (16.7\%).

For the sustainable development of crops and the creation of favorable conditions for the growth and development of plants, and an early harvest, you can use the technology of covering early potato plantings using film stackers. There are various film stackers on the market.

The film-laying machine spapperi SMP, created in Italy, is known for planting herbs and corn seeds with a diameter of more than $4 \mathrm{~mm}$ or in capsules [8]. Working features: the front roller levels the ground and prepares the seed plan - the central roller lays the film - the central wheels ensure constant contact of the film to the ground, facilitating its ridging - the rear plows-hares ridge the soil at the sides of the film, blocking it in position - the cylinders, on the wheels of sowing, after removing the seeds from the appropriate hoppers pneumatically, penetrate the soil by piercing the film. When each cylinder will be in a position perpendicular to the ground, releasing the seed - the rear small wheels compact the soil. Unfortunately, it is not suitable for planting potatoes.

Known film stacker [15] is intended for spreading narrow film mulch material over the rows of sown seeds [14]. It has a number of disadvantages, for example, the size of the soil rolls sprinkled from 
the edges onto the film varies greatly, especially when using narrow film strips, the soil is often poured onto a row of seeds, which leads to the death of seedlings, and in the case of using photodestructible films, solar radiation does not pass to the film, and it does not collapse in the right time and the required amount in terms of area. Therefore, shields are included in the set of working bodies of film-laying machines.

There is a film stacker on the market for laying narrow belts [16]. The film-laying machine contains a frame, on which, for each row, a reel with a film is fixed, which is pressed by a roller against a filmlaying drum. Following it, on each side of the film, sealing working bodies are installed, pouring loose rolls of soil onto the edges of the film in the initial zone of contact with the shields fixed on the beam.

Each flap has a vertical plane, and in the lower part there is an articulated wing with fixation at a given angle $\beta=30 \ldots 45^{\circ}$ to the horizontal. The front part of the vertical plane of each flap is displaced to the row axis and has an angle relative to the row axis equal to $\alpha=10-15^{\circ}$, and the rear part ends directly above the edge of the film, and the loose soil layer, when shifted to the edge of the film during the movement of the film stacker, forms into a dense roller.

The film spreader has a simplified frame design and is designed to spread narrow film mulching material over the rows of sown seeds. The disadvantage of this invention, as shown by tests, is its clogging of soil lumps and plant residues due to the close location of the working edge of the disc harrow and the straight plane of the shield. This is aggravated by the fact that the seed opener, designed for seeding seeds with a film-coated row, has leveling strips that prepare the row surface for the drum and moves large clods of soil away from the seed row, where the disc harrowing area is located. Unloading clods of soil leads to disruption of the technological process of laying out and embedding film strips with soil rollers, reduces the performance of the unit.

To obtain early production of potatoes in a temperate climate zone, it is necessary to use ridge planting for faster soil warming and drying. The height of the ridge may vary depending on the cultivation technology. It is more difficult to lay the film or covering material on the comb, the film or covering material is damaged when it is laid over the comb. The design of the film stacker was proposed, which allows to ensure the optimal water-temperature regime and the quality of the shelter of the ridges, by reducing the damage to the film and its reliable fixation to the soil.

For planting in ridges, the film stacker has a film-folding drum, which is installed with the possibility of height adjustment. Closing working bodies are installed at the end of the leveling tines, which prevents the soil from getting over the film; the alignment flaps are presented in the form of fingers with a minimal patch of contact with the film, which, in turn, reduces the likelihood of it catching and breaking.

Drawings of the film stacker (views: side, top and section) for laying narrow film strips along the ridge with ridge planting of potatoes are shown in Figure 1 ... 2.

The film stacker contains a frame 1 , on which a bobbin 2 with a film 3 is fixed, which is pressed by a pressure roller 4 to a film laying drum 5, installed with the possibility of height adjustment depending on the height of the ridge, followed by on supports 6 fixed on a beam 7 on each side of the film 3 leveling fingers 8 are installed, as well as closing working bodies 9 , pouring loose rollers of soil onto the edges of film 3 into the final contact zone with fingers 8 .

To reduce the spot of contact with the film 3 and reduce the likelihood of its breaking, each finger 8 installed on the support 6 has a minimum inclined plane at a given angle $\beta=30 \ldots 45^{\circ}$ to the horizontal. The front part of each leveling pin 8 is displaced to the row axis and has an angle relative to the row axis equal to $\alpha=10 \ldots 15^{\circ}$, and the rear part ends directly above the edge of the film, and a loose soil layer when shifted to the edge of the film 3 during the movement of the film stacker is formed in a thick roller 10.

The device works as follows: when the film stacker passes over the field over the pre-planted potatoes from the unwinding reel 2 , the film 3 , passing between the pressure roller 4 and under the drum 5 , is then laid over the row by means of the leveling fingers 8 . Following the closing working bodies 9 , on each side, a loose layer of soil is poured onto the edges of the film 3 , which touches the back of the vertical plane of the finger 8 , moves to the edge of the film 3 , forming a dense roller 10 , which reliably fixes and presses the edges of the film 3 to the soil. 


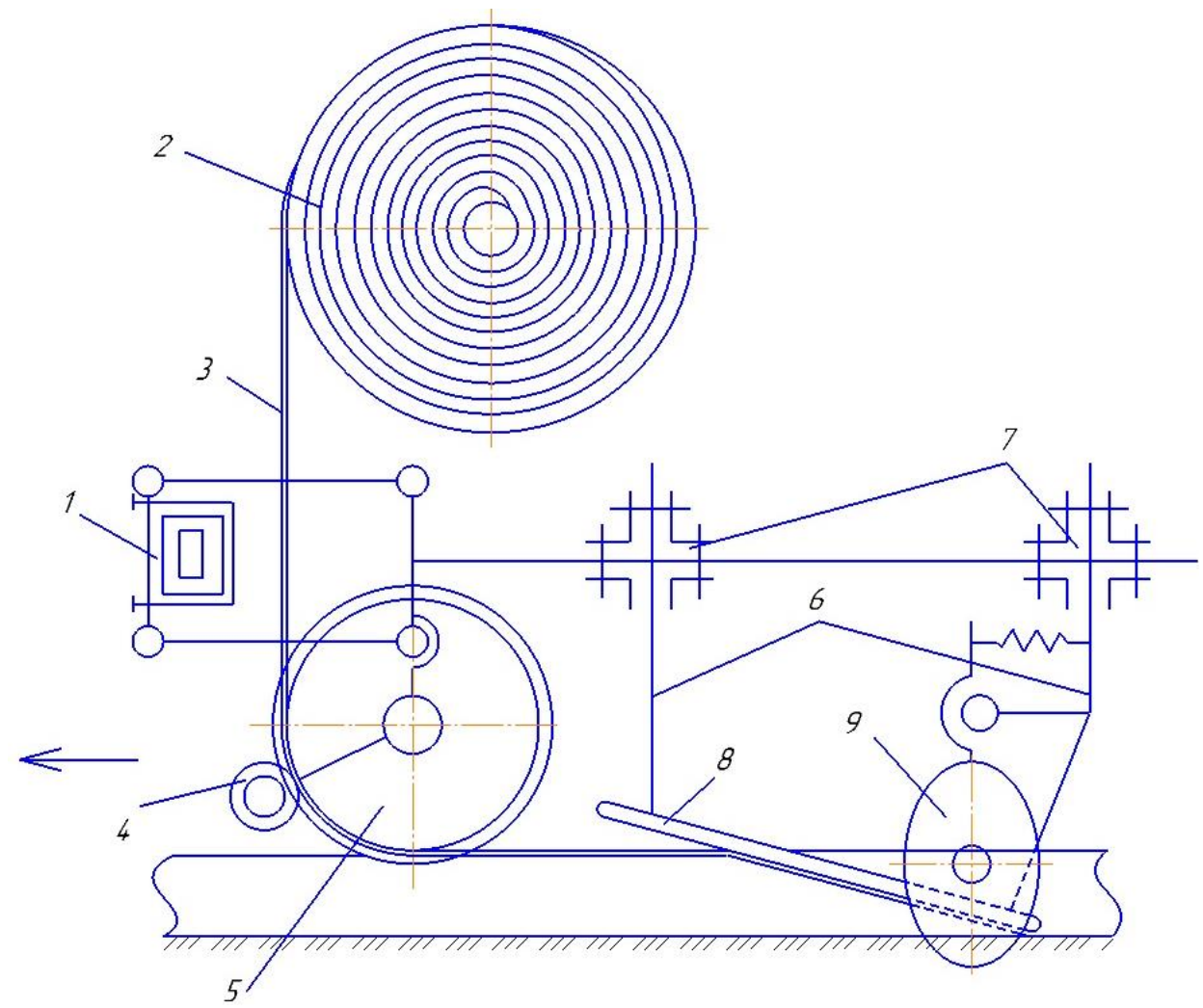

Fig. 1. Scheme of the film stacker machine, side view: 1 - frame; 2 - reel; 3 - covering film; 4 - pressure roller; 5 - film stacker drum; 6 - supports; 7 - beams; 8 - leveling fingers; 9 - covering working bodies

a)

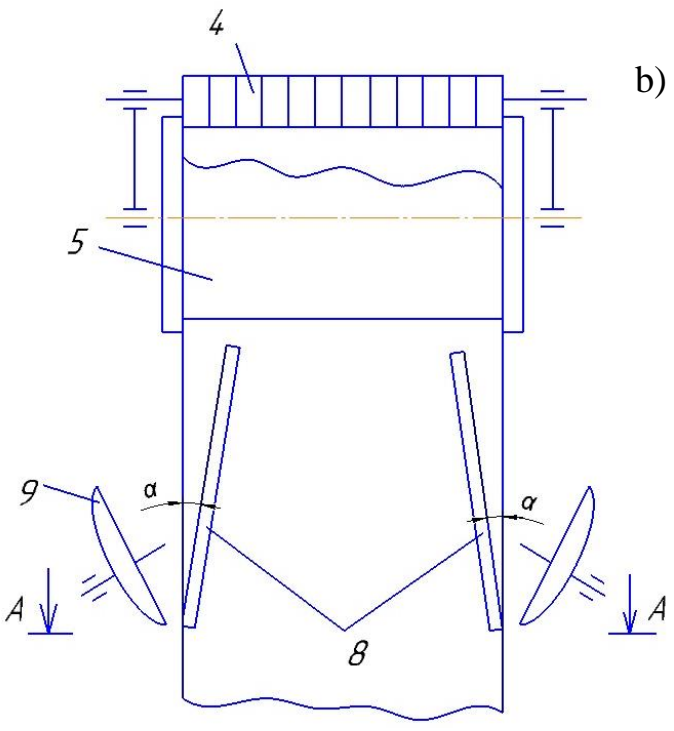

b)

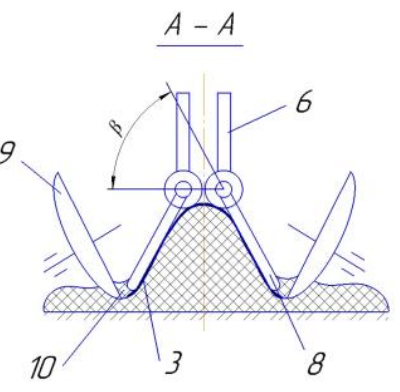

Fig. 2. Layout of the film stacker: $a-$ top view; $b-$ section of the film stacker along $\mathrm{A}-\mathrm{A} ; \beta=30 \ldots 45^{\circ} ; \alpha=10 \ldots 15^{\circ}$

As a result of using a film stacker, damage to the film is reduced, and an optimal water-temperature regime is provided under it.

\section{Conclusions}

The proposed device allows for temporary covering of potato plantings to obtain early production of potatoes. The design features of the film stacker reduce damage to the film and improve the quality of covering the ridges of early potato planting, which provides an optimal water-temperature regime for plants in the first period of plant growth. 


\section{Acknowledgments}

The authors would like to thank their colleagues for their contribution and support to the research. They are also thankful to all the reviewers who gave their valuable inputs to the manuscript and helped in completing the paper.

\section{References}

[1] Климатический хаoc (Climatic chaos) [online] [21.03.2021] Available at: https:// tass.ru/spec/climate (In Russian)

[2] Rosgidromet. [online] [21.03.2021] Available at: http:/www.meteorf.ru/

[3] Ivashova O., Gasparyan I., Levshin A., Dyikanova M. Justification of possibility of cultivating in Moscow region two-crop culture of early potatoes. 19th International Scientific Conference "Engineering for Rural Development", 20-22.05.2020. Jelgava, LATVIA, 2020, pp. 399-405

[4] Diykanova M.E., Levshin A.G., Gasparyan I.N., Deniskina N.F., Ivashova O.N., Mekhedov M.A. Eff ect of temporary covering on early potato yield in the conditions of the Moscow region // Agricultural Engineering, 2020; 6 (100): 31-38. (In Rus.). DOI: 10.26897/2687-1149-2020-6-3138.

[5] Kromer K.-H. Intensivierung mit Mulchfolie (Intensification with mulch film). // Gemüse, 1982. Jg. 18. - №9. - pp. 278-282. (In German)

[6] Krukenberg E. Einsatz synthetischer Mulchmaterialien im Freilandanbau (Use of synthetic mulch materials in outdoor cultivation). // Gartenbau (Berlin), 1991. - Jg.38. - №10. - pp. 6-8. (In German)

[7] Shmyglya V. A., Kinyakin N. F., Kutsamanova I. N. Schutz der kartoffeln vor virusinfektion und beschleunigte vermehrung von gesundem material (Protection of potatoes from viral infection and accelerated reproduction of healthy material). Die Nachrichten der Timirjasewski Landwirtschaftlichen Akademie. 1997. № 4. pp. 133-144. (In German)

[8] Wohlfarth P. Untersuchungen zum Pflanzabstand und zu unterschiedlichen Kulturmaßnahmen bei Rebschulen in Mulchfolien (Investigations into the planting distance and various cultivation measures in nurseries in mulch films). // Bad. Winzer, 1993. - Jg. 18. - №3. - pp. 108-110. (In German)

[9] Hamel J.-M. L'utilisation de paillins plastique en pèpinière (Using plastic mulch in nurseries). // Quebec Vert, 1991. - Vol. 13. - № 4. - pp. 61-65. (In French)

[10] Chirtsov S. P. Device for laying the film over the rows of cotton seeds./S. P. Chirtsov, K. M. Ermatov. // Mechanization and electrification, 1993. - No. 7. - p. 11.

[11] Krukenberg E. Einsatz synthetischer Mulchmaterialien im Freilandanbau (Use of synthetic mulch materials in outdoor cultivation). // Gartenbau (Berlin), 1991. - Jg.38. - №10. - pp. 6-8. (In German)

[12] Ragimov Z. R. Evaluation of the work of the machine for spreading the mulching coating // Mechanization of labor-intensive processes in berry growing. Collection of scientific works. - M., 1983. - pp. 95-102.

[13] Mekhedov M. A. Experimental unit for the formation of ridges of a given profile./M. A. Mekhedov. // Fruit and berry growing in Russia. Collection of scientific works of VSTISP. - M., 2004. - Vol. 11. - p. 459-464.

[14] Kutsamanova, I.N. Methods of improvement of potatoes from viral diseases. Proceedings of the Scientific Conference of Young Scientists and Specialists. Moscow: Publishing house of ICCA, 1999, pp. 49-54.

[15] Chirtsov S. P. Film-laying machine. Utility model patent. RUS 1773338 A1 from 11.07.1992.

[16] Chirtsov S. P., Ermatov K. M. (1991): Film-laying machine for laying narrow strips of film over rows of sown seeds. Utility model patent. RUS 1 660629 A1 from 07.07.1991. 